\title{
No Increase in Rate and Severity of Flares During Pregnancy and Post-Partum Period in Pregnant Patients with Systemic Lupus Erythematosus. A Sex, Age and Disease Duration Matched Controlled Study
}

Worawit Louthrenoo ( $\square$ worawit.louthrenoo@cmu.ac.th )

Chiang Mai University Faculty of Medicine https://orcid.org/0000-0003-3105-6122

Thananant Trongkamolthum

Chiang Mai University Faculty of Medicine

Nuntana Kasitatnon

Chiang Mai University Faculty of Medicine

Antika Wongthanee

Chiang Mai University Faculty of Medicine

Research article

Keywords: SLE, systemic lupus erythematosus, pregnancy, flares, disease activity

Posted Date: September 2nd, 2020

DOl: https://doi.org/10.21203/rs.3.rs-70135/v1

License: (c) (i) This work is licensed under a Creative Commons Attribution 4.0 International License. Read Full License 


\section{Abstract}

Background: Flares in pregnant patients with systemic lupus erythematosus (SLE) have shown conflicting results. This study aimed to determine the disease activity, and rate and severity of flares in pregnant SLE patients compared with the non-pregnant SLE controls.

Methods: The medical records of pregnant patients in the SLE cohort were identified. Controls were non-pregnant female SLE patients who were matched for age at diagnosis and disease duration prior to conception. Disease activity was determined by mSLEDAI-2K. The definition and severity of flares followed the SELANA-SLEDAI Flare Index. The disease activity was measured from 6 months prior to conception (-6M) until termination of pregnancy or delivery.

Results: Ninety pregnancies occurred from 77 patients, of whom $36.67 \%$ had active disease at the time of conception. The pregnancy group was slightly, but significantly, younger than the control group at diagnosis (21.63 \pm 5.89 years vs. $24.05 \pm 7.27$ years, $p=0.015$ ). The SLE disease activity (mSLEDAI-2K) score was comparable in both groups from $-6 \mathrm{M}$ to the post-partum period, with that in the control group being slightly but significantly higher than that in the pregnancy group at conception (3.57 \pm 4.28 vs. $1.91 \pm 3.44, p=0.003)$. Of the 90 pregnancies, the overall incidence of flares in both groups was similar during pregnancy (39 vs. $26, p=0.070$ ). There also was no difference in the incidence of flare during each trimester, with $19 \mathrm{vs.} 7$ flares among 90 pregnancies $(p=0.588)$ in the $1^{\text {st }}, 12$ vs. 12 among $82(p=0.682)$ in the $2^{\text {nd }}$, and 6 vs. 7 among $71(p=0.266)$ in the $3^{\text {rd }}$ trimester. The incidence of flare during the post-partum period also was similar (42 vs. 30 flares among 90 pregnancies, $p=0.091$ ). There was no difference in the severity of flare in each trimester, overall flare during pregnancy or post-partum flare.

Conclusions: This study found no difference in flare rate or severity of flares between pregnant SLE patients and nonpregnant SLE controls, who were matched by sex, age at diagnosis and disease duration prior to pregnancy.

\section{Background}

Pregnancy in systemic lupus erythematosus (SLE) is an interesting issue, as the disease can affect both maternal and fetal outcomes. It is believed commonly that SLE usually exacerbates during pregnancy. The flare rate in SLE patients during pregnancy reportedly ranges from 13 to $65 \%$ [1, 2]. This wide range might have been related to the study design (either prospective or retrospective, or controlled or un-controlled), study entry criteria, and the criteria or methods used to determine SLE disease activity and flares, as well as the instrument used for flare determination. The flare and adverse outcomes usually occur while the disease is still active during pregnancy. Because active and exacerbated disease (or flares) during pregnancy can have negative impact on both maternity and the fetus, it is suggested that SLE patients avoid pregnancy if they have had severe active disease within the previous 6 months, or significant heart, lung, renal and central nervous system involvement $[1,2]$. In addition, certain clinical manifestations during pregnancy such as malar and palmar erythema, arthralgia, myalgia, edema of the legs, and slightly reduced hemoglobin level, as well as increasing proteinuria or erythrocyte sedimentation rate can be seen in normal pregnancy and be confused with flares [3].

Whether the rate of flare seen in pregnant SLE patients is higher or similar to that observed in non-pregnant SLE ones is still debatable. Even among previous case-controlled studies, not only were the number of studies limited, but also with conflicting results [4-10]. Unfortunately, many of these studies were performed prior to 1990 and the instruments used to determine SLE disease activity or flares were not defined clearly.

The aim of this study was to compare disease activity and rate of flares in pregnant SLE patients to that in nonpregnant SLE patients. Because age at onset [11-13] and duration of the disease [14,15] influence the clinical 
manifestations, and pregnancy in SLE patients is recommended for those in SLE remission or having low disease activity for at least 6 months; therefore, never-pregnant female SLE patients in the same lupus cohort who were matched with age at diagnosis and disease duration prior to conception were used as controls. The comparison in SLE disease activity and flares was determined from 6 months prior to conception (-6M) to the post-partum period.

\section{Methods}

The medical records of SLE patients in the lupus cohort of the Division of Rheumatology, Faculty of Medicine, Chiang Mai University, seen between January 1993 and June 2017, were reviewed. All of the patients were diagnosed SLE according to the 1997 updating the American College of Rheumatology (ACR) revised criteria for the classification of SLE [16]. All of the SLE patients in the cohort were followed prospectively at 1-3 month intervals; however, the duration of the follow up was more or less frequent, depending on disease activity or any other clinical encounters. The clinical manifestations and laboratory findings were recorded prospectively at every visit.

In this study, pregnant SLE patients (cases) were identified. Pregnancy data were collected from - $6 \mathrm{M}$ until 6 weeks after pregnancy termination or delivery (post-partum period). SLE disease activity at $-6 \mathrm{M}, 3$ months prior to conception $(-3 \mathrm{M})$, at the time of conception, the 1 st trimester, 2 nd trimester, 3rd trimester and post-partum period was calculated based on the clinical and laboratory findings. If a patient had more than one visit during one of these periods, the mean SLE disease activity of that period was used for statistical analysis. If the patients had more than one pregnancy, each pregnancy was counted as a patient.

The controls were non-pregnant female SLE patients in the same cohort. They had never been pregnant, had the closest hospital number, had their age at SLE diagnosis of within 5 years, and had at least similar duration of follow-up to the matched pregnant patients. In order to compare SLE disease activity and rate of flares between the controls and cases, the clinical manifestation and SLE disease activity of the controls, which corresponded to the visiting dates of the cases from $-6 \mathrm{M}$ to the post-partum period, also were calculated. If a pregnant patient had more than one pregnancy, the clinical manifestation and SLE disease activity of the controls were captured and used for analysis, similar to that of the cases.

Details of clinical manifestation from SLE onset and during pregnancy (-6M to the post-partum period) and treatment in both the cases and controls were recorded. Laboratory investigation including complete blood counts, urine analysis, 24-hour urine protein creatinine ratio (24hr UPCI) in cases with lupus nephritis, and renal and liver functions were recorded routinely. As anti-dsDNA and complements (C3 and C4) were not available routinely at this institution, the modified Systemic Lupus Erythematosus Disease Activity Index (mSLEDAI-2K score) was used to determine SLE disease activity both in the cases and controls [17]. In addition, the Systemic Lupus Erythematosus Pregnancy Disease Activity Index (SLEPDAI) also determined SLE disease activity in the cases [18]. The SLEPDAI in this study was modified by excluding the complement level (mSLEPDAl).

In this study, the severity of SLE disease activity was classified in accordance with Abrahamowicz et al. [19], but the mSLEDAI-2K was used instead of the original Systemic Lupus Erythematosus Disease Activity Index (SLEDAI) score. The disease severity was described as follows: remission ( $\mathrm{mSLEDAI}-2 \mathrm{~K}=0$ ), mild activity (mSLEDAI-2K = 1-5), moderate activity (mSLEDAI-2K = 6-10), high disease activity (mSLEDAI-2K = 11-19) and very high disease activity ( $m$ SLEDAI-2K $=\geq 20$ ). The degree of SLE flare followed the Safety of Estrogens in Lupus Erythematosus National Assessment (SELENA) SLE flare index (SFI) [20]. As the physician global assessment (PGA) was not recorded routinely, the SFI was modified by excluding the PGA items (mSFI). The mSLEDAI-2K score and mSFI were calculated retrospectively, based on the clinical and laboratory findings in the medical recorded. In this study, lupus activity at the 
time of conception was not considered as a flare, and only increasing disease activity or treatment according to the SFI was thought to be one. Flares were treated according to the best judgment of the physician.

The patients at the clinic should have been in clinical remission or in stable low disease activity, and taking prednisolone $\leq 10 \mathrm{mg} /$ day without immunosuppressive drugs (other than anti-malarial treatment) for a minimum of 12 months in order to allow pregnancy. If the patients were receiving immunosuppressive cyclophosphamide or mycophenolate mofetil and became pregnant, these 2 drugs would be discontinued immediately and replaced by azathioprine or cyclosporine, where appropriate. Anti-malarial treatment was allowed throughout the pregnancy period.

This study was performed in accordance with the ethical standards of the institutional and/or national research committee and the 1964 Helsinki declaration and its later amendments or comparable ethical standards. It also was approved by the Ethic Committee of the Faculty of Medicine, Chiang Mai University (No. 215/2017).

\section{Statistical analysis}

STATA 14.2 computer software (Stata Corporation, Texas USA) was used for data processing and statistical analysis. As some patients had more than one pregnancy, this study considered each pregnancy for each individual patient for statistical analysis. Continuous variables were presented as mean \pm standard deviation (SD) or standard error of mean (SEM), and categorical variables were presented as percent. The Student's t-test, Wilcoxon rank sum test or Sign rank rest was used to determine the differences between the two continuous variables, with normal and non-normal distribution, where appropriate. The Chi-square test or Fisher exact test was used to determine differences among the categorical variables, where appropriate. Analysis of Covariance (ANCOVA) was used to determine the differences between groups for continuous outcome variables when covariate variables were included. The logistic regression was used for the binary outcome variables. Concordance correlation coefficient and Kappa statistic were used to determine the agreement between mSLEPDAI and mSLEDAI-2K scores. Comparison of means and proportions of two or more measurements, repeated over a period on the same subject, were determined by the repeated measures mixed model and generalized estimation equation, respectively. A $p \leq 0.05$ was considered as a statistically significant difference.

\section{Results}

\section{Demographics and characteristics of pregnant SLE patients and non-pregnant SLE controls}

There were 90 pregnancies from 77 patients (1,2 and 3 pregnancies in 66, 9 and 2 patients, respectively) during the study period. None of the pregnant SLE patients or controls were alcohol drinkers or smokers. Seven patients were diagnosed SLE at the time of conception; therefore, the activity of SLE at the time of conception also was used to determine SLE disease activity at $-6 \mathrm{M}$ and $-3 \mathrm{M}$. SLE was diagnosed at the time of conception in 7 pregnancies (7.78\%), and within 5 years before and after SLE diagnosis in 49 (54.4\%), and 34 (37.78\%), respectively. Among the 90 pregnancies, $45(50.00 \%)$ were a first pregnancy, 25 (27.78\%) a second one, and $20(22.22 \%)$ a third one or more. Thirtythree of the 90 pregnancies (36.67\%) were considered active at the time of conception (mSLEDAl score >0).

The demographics and characteristics of the pregnant SLE patients and controls are shown in Table 1. Patients in the pregnancy group had slightly, but significantly, lower age at SLE onset (21.63 \pm 5.89 years vs. $24.05 \pm 7.27$ years, $p=$ 0.015 ) than the control group. In addition, the pregnancy group had significantly higher cumulative prevalence of facial rashes and photosensitivity when compared with the controls. However, it had significantly lower prevalence of dyslipidemia, presence of anti-dsDNA antibodies and lupus anticoagulants. Although the SLE disease activity (mSLEDAI-2K) and medication used at -6M were no different between the two groups; the SLE disease activity, mean 
daily dose of prednisolone and use of immunosuppressive drugs at conception were significantly higher in the control group $(3.57 \pm 4.28$ vs. $1.91 \pm 3.44, p=0.003,12.24 \pm 14.14 \mathrm{mg} /$ day vs. $8.74 \pm 11.37 \mathrm{mg} /$ day, $\mathrm{p}=0.018$, and $45.56 \%$ vs . $24.44 \%, p=0.003$, respectively). 
Table 1

Demographics and characteristics of pregnant SLE patients and controls

\begin{tabular}{|c|c|c|c|}
\hline Characteristics & $\begin{array}{l}\text { Pregnancy group } \\
(\mathrm{N}=90)\end{array}$ & $\begin{array}{l}\text { Control group } \\
(\mathrm{N}=90)\end{array}$ & p-value \\
\hline Age at SLE diagnosis (years) & $21.63 \pm 5.89$ & $24.05 \pm 7.27$ & 0.015 \\
\hline Disease duration prior to pregnancy & $5.36 \pm 5.12$ & $5.24 \pm 4.45$ & 0.674 \\
\hline Age at pregnancy (years) & $26.94 \pm 4.80$ & & \\
\hline Duration of pregnancy (weeks) & $31.41 \pm 9.56$ & & \\
\hline \multicolumn{4}{|l|}{ Co-morbidities } \\
\hline Hypertension, n (\%) & $23(25.56)$ & $15(16.67)$ & 0.144 \\
\hline Diabetes, n (\%) & $1(1.11)$ & $4(4.44)$ & 0.368 \\
\hline Dyslipidemia, n (\%) & $8(8.89)$ & $19(21.11)$ & 0.022 \\
\hline Old pulmonary TB, n (\%) & $1(1.11)$ & 0 & 1.000 \\
\hline Thalassemia, n (\%) & $7(7.78)$ & $4(4.44)$ & 0.351 \\
\hline \multicolumn{4}{|c|}{ Cumulative clinical manifestations at 6 months prior to conception } \\
\hline Facial rashes & $61(67.78)$ & $46(51.11)$ & 0.023 \\
\hline Oral ulcers & $31(34.44)$ & $28(31.11)$ & 0.634 \\
\hline Photosensitivity & $36(40.00)$ & $19(21.11)$ & 0.006 \\
\hline Discoid rashes & $34(37.78)$ & $34(37.78)$ & 1.000 \\
\hline Arthritis & $50(55.56)$ & $52(57.78)$ & 0.764 \\
\hline Serositis & $9(10.00)$ & $12(13.33)$ & 0.486 \\
\hline Neurological involvement & $10(11.11)$ & $7(7.78)$ & 0.445 \\
\hline Hematologic involvement & $57(63.33)$ & $67(74.44)$ & 0.107 \\
\hline Renal involvement & $72(80.00)$ & $64(71.11)$ & 0.165 \\
\hline ANA, n (\%) & 89 (98.89) & 89 (98.89) & 1.000 \\
\hline Anti-dsDNA ${ }^{\mathrm{a}}, \mathrm{n}(\%)$ & $50 / 85(58.82)$ & $65 / 84(77.38)$ & 0.010 \\
\hline Anti-Sm ${ }^{\mathrm{a}}, \mathrm{n}(\%)$ & $1 / 12(8.33)$ & $1 / 1(100.00)$ & 0.154 \\
\hline Anti-cardiolipin ${ }^{a}$, n (\%) & $4 / 58(6.90)$ & $5 / 42(11.90)$ & 0.388 \\
\hline Lupus anticoagulant ${ }^{\mathrm{a}}, \mathrm{n}(\%)$ & $3 / 42(7.14)$ & 8/33 (24.24) & 0.038 \\
\hline Anti-Ro ${ }^{a}, n(\%)$ & $21 / 46(45.65)$ & 7/18 (38.89) & 0.624 \\
\hline
\end{tabular}

Data are expressed as mean \pm SD unless indicated otherwise; ${ }^{a}=$ number of positive tests $/$ number of tested; ${ }^{b}=$ some patients received more than one immunosuppressive drug, mSLEDAl-2K = modified Systemic Lupus

Erythematosus Disease Activity Index - 2000, mSLEPDAl = modified Systemic Lupus Erythematosus Pregnancy Disease Activity Index. 


\begin{tabular}{|c|c|c|c|}
\hline Characteristics & $\begin{array}{l}\text { Pregnancy group } \\
(\mathrm{N}=90)\end{array}$ & $\begin{array}{l}\text { Control group } \\
(\mathrm{N}=90)\end{array}$ & p-value \\
\hline Anti-La ${ }^{a}, \mathrm{n}(\%)$ & $20 / 47(42.56)$ & 6/18 (33.33) & 0.497 \\
\hline SLICC score & $0.40 \pm 0.72$ & $0.29 \pm 0.66$ & 0.255 \\
\hline \multicolumn{4}{|l|}{6 months prior to conception } \\
\hline Disease activity (mSLEDAI-2K) & $1.72 \pm 3.22$ & $2.79 \pm 4.26$ & 0.098 \\
\hline \multicolumn{4}{|l|}{ Medication used } \\
\hline No medication, n (\%) & $14(15.56)$ & $6(6.67)$ & 0.058 \\
\hline Prednisolone, n (\%) & $73(81.11)$ & $80(88.89)$ & 0.144 \\
\hline Prednisolone dose, mg/day & $8.19 \pm 9.40$ & $12.15 \pm 14.24$ & 0.110 \\
\hline Hydroxychloroquine, n (\%) & $36(40.00)$ & $43(47.78)$ & 0.293 \\
\hline Immunosuppressive drugs ${ }^{\mathrm{b}}, \mathrm{n}(\%)$ & $27(30.00)$ & $38(42.22)$ & 0.088 \\
\hline \multicolumn{4}{|l|}{ At conception } \\
\hline Disease activity (mSLEDAI-2K) & $1.91 \pm 3.44$ & $3.57 \pm 4.28$ & 0.003 \\
\hline Disease activity (mSLEPDAI ) & $1.90 \pm 3.44$ & & \\
\hline \multicolumn{4}{|l|}{ Medication used } \\
\hline No medication, n (\%) & $17(18.89)$ & $8(8.89)$ & 0.060 \\
\hline Prednisolone, n (\%) & $73(81.11)$ & $82(91.11)$ & 0.843 \\
\hline Prednisolone dose, mg/day & $8.74 \pm 11.37$ & $12.24 \pm 14.14$ & 0.018 \\
\hline Hydroxychloroquine, n (\%) & $37(41.11)$ & $43(47.78)$ & 0.368 \\
\hline Immunosuppressive drugs ${ }^{\mathrm{b}}, \mathrm{n}(\%)$ & $22(24.44)$ & $41(45.56)$ & 0.003 \\
\hline \multicolumn{4}{|c|}{$\begin{array}{l}\text { Data are expressed as mean } \pm \text { SD unless indicated otherwise; }{ }^{a}=\text { number of positive tests } / \text { number of tested; }{ }^{b}= \\
\text { some patients received more than one immunosuppressive drug, mSLEDAl-2K }=\text { modified Systemic Lupus } \\
\text { Erythematosus Disease Activity Index }-2000, \text { mSLEPDAl = modified Systemic Lupus Erythematosus Pregnancy } \\
\text { Disease Activity Index. }\end{array}$} \\
\hline
\end{tabular}

At the time of conception, 4 and 6 patients received mycophenolate mofetil and cyclophosphamide, respectively; and these 2 medicines were switched to azathioprine and cyclosporine, respectively. The pregnancies terminated in the $1 \mathrm{st}$, 2nd and 3rd trimester in 8, 11 and 71 pregnancies, respectively. Nineteen pregnancies ended in pregnancy loss (spontaneous abortion in 12 [ 7 in the 1st trimester, and 5 in the 2 nd ], induced abortion in 5 [ 1 in the 1 st trimester, and 4 in the $2 \mathrm{nd}$ ], stillbirth in 1 [in the 2nd trimester], and dead fetus in the utero in 1 [in the 3rd trimester]). There were 28 full term and 43 premature (one was a twin pregnancy) deliveries and 1 post-term delivery.

\section{Correlation between the mSLEDAl-2K and mSLEPDAI}


The correlation between the mSLEDAI-2K and mSLEPDAI scores in pregnant SLE patients was determined from the time of conception to termination of pregnancy or delivery, and it was found that both scores showed very good correlation (slope 1.002, $r=0.988, p<0.001$ ). Thus, the mSLEDAI-2K was used to compare SLE disease activity between the pregnancy and control group.

\section{SLE disease activity, active organ involvement, flares and flare rate during pregnancy}

Changes in SLE disease activity among the all pregnancy and controls groups and their subgroup based on the degree of SLE disease activity (remission, mild, and moderate and high) from - 6M to the third trimester, are shown in Table 2 and Supplementary Fig. 1). As the number of patients with moderate and high disease activity was small, these 2 groups were combined into one for statistical analysis. Also, as there was a significant difference in the age at SLE onset, and the mSLEDAI-2K score, the daily dose of prednisolone and immunosuppressive drugs used at the time of conception, these 4 variables were controlled in the analysis. 
Table 2

SLE disease activity (mSLEDAI-2K) and number of patients according to disease severity both in the pregnancy and control group, from 6 months prior to conception and in each trimester

\section{SLE disease activity (mSLEDAl-2K score)}

Period of evaluation

\begin{tabular}{|c|c|c|c|}
\hline $6 \mathrm{M}$ & $-3 M$ & Conception & $\begin{array}{l}\text { 1st } \\
\text { trimester }\end{array}$ \\
\hline
\end{tabular}

\section{All cases}

\begin{tabular}{|c|c|c|c|c|c|c|}
\hline Pregnancy group, $\mathrm{n}$ & 90 & 90 & 90 & 90 & 82 & 71 \\
\hline Mean \pm SEM & $\begin{array}{l}1.72 \pm \\
0.34\end{array}$ & $\begin{array}{l}2.04 \pm \\
0.40\end{array}$ & $1.91 \pm 0.36$ & $\begin{array}{l}2.59 \pm \\
0.41\end{array}$ & $\begin{array}{l}2.78 \pm \\
0.45^{a}\end{array}$ & $\begin{array}{l}2.58 \pm \\
0.46^{b}\end{array}$ \\
\hline Control group, $\mathrm{n}$ & 90 & 90 & 90 & 90 & 82 & 71 \\
\hline Mean \pm SEM & $\begin{array}{l}2.79 \pm \\
0.45\end{array}$ & $\begin{array}{l}2.98 \pm \\
0.39\end{array}$ & $3.57 \pm 0.45$ & $\begin{array}{l}2.57 \pm \\
0.38^{h}\end{array}$ & $\begin{array}{l}2.43 \pm \\
0.39^{i}\end{array}$ & $\begin{array}{l}2.38 \pm \\
0.47^{j}\end{array}$ \\
\hline$p$-value & & 0.309 & 0.019 & 0.453 & 0.379 & 0.262 \\
\hline \multicolumn{7}{|c|}{ Remission (mSLEDAl-2K = 0) } \\
\hline Pregnancy group, n (\%) & $\begin{array}{l}61 \\
(67.77)\end{array}$ & $\begin{array}{l}61 \\
(67.77)\end{array}$ & $61(67.77)$ & $\begin{array}{l}61 \\
(67.77)\end{array}$ & $55(67.07)$ & $49(69.01)$ \\
\hline Mean \pm SEM & 0 & $\begin{array}{l}0.74 \pm \\
0.41\end{array}$ & $0.74 \pm 0.31$ & $\begin{array}{l}1.84 \pm \\
0.47^{c}\end{array}$ & $\begin{array}{l}2.25 \pm \\
0.55^{d}\end{array}$ & $\begin{array}{l}2.06 \pm \\
0.56^{\mathrm{e}}\end{array}$ \\
\hline Control group, n (\%) & $\begin{array}{l}52 \\
(57.78)\end{array}$ & $\begin{array}{l}52 \\
(57.58)\end{array}$ & $52(57.58)$ & $\begin{array}{l}52 \\
(57.78)\end{array}$ & $49(59.76)$ & $41(57.75)$ \\
\hline Mean \pm SEM & 0 & $\begin{array}{l}1.38 \pm \\
0.38\end{array}$ & $2.67 \pm 0.58$ & $\begin{array}{l}1.36 \pm \\
0.38^{k}\end{array}$ & $\begin{array}{l}1.86 \pm \\
0.48\end{array}$ & $\begin{array}{l}1.83 \pm \\
0.57\end{array}$ \\
\hline p-value & & 0.241 & 0.001 & 0.496 & 0.663 & 0.722 \\
\hline \multicolumn{7}{|l|}{ Mild (mSLEDAl-2K = 1-5) } \\
\hline Pregnancy group, n (\%) & $\begin{array}{l}19 \\
(21.11)\end{array}$ & $\begin{array}{l}19 \\
(21.11)\end{array}$ & $19(21.11)$ & $\begin{array}{l}19 \\
(21.11)\end{array}$ & $18(21.95)$ & $16(22.53)$ \\
\hline Mean \pm SEM & $\begin{array}{l}3.21 \pm \\
0.25\end{array}$ & $\begin{array}{l}3.10 \pm \\
0.42\end{array}$ & $3.95 \pm 0.79$ & $\begin{array}{l}3.95 \pm \\
0.82\end{array}$ & $\begin{array}{l}3.44 \pm \\
0.80\end{array}$ & $\begin{array}{l}4.00 \pm \\
1.05\end{array}$ \\
\hline Control group, n (\%) & $\begin{array}{l}18 \\
(20.00)\end{array}$ & $\begin{array}{l}18 \\
(20.00)\end{array}$ & $18(20.00)$ & $\begin{array}{l}18 \\
(20.00)\end{array}$ & $17(20.73)$ & $16(22.53)$ \\
\hline Mean \pm SEM & $\begin{array}{l}3.11 \pm \\
0.24\end{array}$ & $\begin{array}{l}2.89 \pm \\
0.46\end{array}$ & $3.11 \pm 0.54$ & $\begin{array}{l}3.11 \pm \\
0.56\end{array}$ & $\begin{array}{l}2.94 \pm \\
0.62\end{array}$ & $\begin{array}{l}3.00 \pm \\
0.93\end{array}$ \\
\hline$p$-value & & 0.777 & 0.363 & 0.363 & 0.599 & 0.314 \\
\hline
\end{tabular}

The repeated measures mixed model was used for analysis and controlled by age at SLE onset and mSLEDAI-2K, daily dose of prednisolone and use of immunosuppressive drugs. mSLEDAl-2K = modified SLE disease activity index, $-6 \mathrm{M}=6$ months prior to conception, $-3 \mathrm{M}=3$ months prior to conception.

$\mathrm{a}-\mathrm{g}=\mathrm{p}$ value of the mSLEDAI-2K score in the pregnancy group, compared between the time of conception and $1 \mathrm{st}$, 2nd and 3rd trimester ( $a, p=0.040 ; b, p=0.028 ; c, p=0.020 ; d, p=0.002 ; e, p=0.005 ; f . p=0.008 ; g, p=0.002)$.

$\mathrm{h}-\mathrm{m}=\mathrm{p}$ value of the mSLEDAI-2K score in the control group, compared between the time of conception and $1 \mathrm{st}, 2 \mathrm{nd}$ and 3rd trimester, corresponding to time in the pregnancy group $(h, p=0.010 ; i, p=0.018 ; j, p=0.015 ; k, p=0.011 ; l$, $p=0.008 ; m=0.002)$. 


\begin{tabular}{|c|c|c|c|c|c|c|}
\hline \multirow{2}{*}{$\begin{array}{l}\text { SLE disease activity (mSLEDAl-2K } \\
\text { score) }\end{array}$} & \multicolumn{6}{|c|}{ Period of evaluation } \\
\hline & $-6 M$ & $-3 M$ & Conception & $\begin{array}{l}1 \text { st } \\
\text { trimester }\end{array}$ & $\begin{array}{l}\text { 2nd } \\
\text { trimester }\end{array}$ & $\begin{array}{l}\text { 3rd } \\
\text { trimester }\end{array}$ \\
\hline \multicolumn{7}{|l|}{$\begin{array}{l}\text { Moderate and high (mSLEDAl-2K } \\
\geq 6 \text { ) }\end{array}$} \\
\hline Pregnancy group, n (\%)) & $\begin{array}{l}10 \\
(11.11)\end{array}$ & $\begin{array}{l}10 \\
(11.11)\end{array}$ & $10(11.11)$ & $\begin{array}{l}10 \\
(11.11)\end{array}$ & $9(10.98)$ & $6(8.45)$ \\
\hline Mean \pm SEM & $\begin{array}{l}9.40 \pm \\
0.99\end{array}$ & $\begin{array}{l}8.00 \pm \\
1.30\end{array}$ & $5.20 \pm 1.53$ & $\begin{array}{l}4.60 \pm \\
1.55\end{array}$ & $\begin{array}{l}4.67 \pm \\
1.60^{f}\end{array}$ & $\begin{array}{l}3.00 \pm \\
1.12 \mathrm{~g}\end{array}$ \\
\hline Control group, n (\%) & $\begin{array}{l}20 \\
(22.22)\end{array}$ & $\begin{array}{l}20 \\
(22.22)\end{array}$ & $20(22.22)$ & $\begin{array}{l}20 \\
(22.22)\end{array}$ & $16(19.51)$ & $14(19.72)$ \\
\hline Mean \pm SEM & $\begin{array}{l}9.75 \pm \\
0.77\end{array}$ & $\begin{array}{l}7.20 \pm \\
0.89\end{array}$ & $6.30 \pm 1.09$ & $\begin{array}{l}5.20 \pm \\
1.10\end{array}$ & $\begin{array}{l}3.62 \pm \\
1.19^{1}\end{array}$ & $\begin{array}{l}3.28 \pm \\
1.32 \mathrm{~m}\end{array}$ \\
\hline$p$-value & & 0.670 & 0.529 & 0.725 & 0.759 & 0.908 \\
\hline \multicolumn{7}{|c|}{$\begin{array}{l}\text { The repeated measures mixed model was used for analysis and controlled by age at SLE onset and mSLEDAI-2K, } \\
\text { daily dose of prednisolone and use of immunosuppressive drugs. mSLEDAl-2K = modified SLE disease activity } \\
\text { index, }-6 \mathrm{M}=6 \text { months prior to conception, }-3 \mathrm{M}=3 \text { months prior to conception. }\end{array}$} \\
\hline \multicolumn{7}{|c|}{$\begin{array}{l}a-g=p \text { value of the mSLEDAI-2K score in the pregnancy group, compared between the time of conception and } 1 \text { st, } \\
\text { 2nd and 3rd trimester }(a, p=0.040 ; b, p=0.028 ; c, p=0.020 ; d, p=0.002 ; e, p=0.005 ; f . p=0.008 ; g, p=0.002) \text {. }\end{array}$} \\
\hline \multicolumn{7}{|c|}{$\begin{array}{l}h-m=p \text { value of the mSLEDAl-2K score in the control group, compared between the time of conception and } 1 \mathrm{st}, 2 n d \\
\text { and 3rd trimester, corresponding to time in the pregnancy group }(h, p=0.010 ; i, p=0.018 ; j, p=0.015 ; k, p=0.011 ; l \text {, } \\
p=0.008 ; m=0.002) \text {. }\end{array}$} \\
\hline
\end{tabular}

The mSLEDAI-2K score in the pregnancy group was slightly lower than that of the controls at $-6 \mathrm{M}$ and $-3 \mathrm{M}$, but it became lower with statistical significance at the time of conception $(1.91 \pm 0.36$ vs. $3.57 \pm 0.45, p=0.019)$. The mSLEDAI-2K score in the pregnancy group slightly increased in the 1st, 2nd and 3rd trimester when compared with the time of conception, however, it did not show any statistically significant difference from the control group. In the subgroup analysis, those who were in clinical remission at $-6 \mathrm{M}(\mathrm{mSLEDAI}-2 \mathrm{k}=0)$ had an mSLEDAI-2K score that increased from - $3 \mathrm{M}$ to the 3rd trimester in both groups, but it was significantly higher in the control group than in the pregnancy group only at the time of conception ( $0.74 \pm 0.31$ vs. $2.67 \pm 0.58, p=0.001)$. There was no significant difference in mean mSLEDAI-2K score between the pregnancy and control group from - $6 \mathrm{M}$ to the 3rd trimester among patients with mild, or moderate and high disease activity.

The effect of pregnancy on SLE disease activity was determined. The disease activity (mSLEDAl-2K score) at the time of conception was compared with the 1st, 2nd and 3rd trimester in both the pregnancy and control group, and the results are shown in Table 2. The mSLEDAI-2K score in the all pregnancy group increased slightly and gradually after conception and became statistically higher at the $2 \mathrm{nd}$ and 3rd trimester. Pregnant patients with disease in remission at $-6 \mathrm{M}$ had a slightly and progressively increasing mSLEDAI-2K score which was significantly higher in all the trimesters than at the time of conception. The mSLEDAI-2K score in those with mild disease activity at $-6 \mathrm{M}$ did not show any significant changes after conception throughout the pregnancy period. It was interesting that the mSLEDAI-2K score in pregnant patients with moderate and high disease activity at $-6 \mathrm{M}$ showed a progressive decline, which was significantly lower than at the time of conception at the $2 \mathrm{nd}$ and 3rd trimester. On the other hand, all of the patients in the control group had progressive decrease, but significantly, in the mSLEDAI-2K score at the 1st, 2nd and 3rd trimesters, when compared with the time of conception. The controls with disease in remission at $-6 \mathrm{M}$ had a lower 
mSLEDAI-2K score after conception, which was statistically lower than that at the time of conception at the 1 st trimester only. There was no significant change in the mSLEDAI-2K score in the control group with mild disease activity at $-6 \mathrm{M}$ after conception during the pregnancy period. The mSLEDAI-2K score among the controls with moderate and high disease activity at $-6 \mathrm{M}$ declined progressively after conception and was significantly lower at the $2 \mathrm{nd}$ and $3 \mathrm{rd}$ trimester. These mSLEDAl-2K changes within the pregnancy and control group, although statically significance, ranged between $0.87-2.20$ and 1.31-3.02, respectively. Results of these comparisons ( $\mathrm{a}$ to $\mathrm{m}$ ) are shown at the footnote in Table 2.

Active organ involvement seen during the study from $-6 \mathrm{M}$ to the 3rd trimester, both in the pregnancy and control groups, are shown in Supplementary Table 1. Renal involvement (mostly proteinuria), mucocutaneous lesions, and hematologic abnormalities were the 3 most common organs involved and seen in $21.11-36.62 \%, 11.27-18.89 \%$ and 0 $6.67 \%$ of the pregnancies, respectively. However, only hematologic abnormalities were seen to be significantly more common at $-6 \mathrm{M}$ in the control than in the pregnancy group $(6.67 \% \mathrm{vs} .0 \%, \mathrm{p}=0.029)$.

The incidence and categories of flares among the pregnancy and control group in each trimester are shown in Table 3. The overall number of flares was higher numerically in the pregnancy than in the control group, but this did not reach statistical significance (37 in 90 pregnancies [41.11\%] vs. 26 in 90 pregnancies [28.89\%], $p=0.070$ ). Subgroup analysis of flares in patients who were in remission, and had mild, or moderate and high disease activity at the time at conception, did not show any significant differences in flare rate. The 37 flares in the pregnancy group occurred in the 1st, 2nd and 3rd trimester in 19 of 90 (21.11\%), 28 of 82 (34.15\%), and 28 of 71 (39.44\%) pregnancies, respectively. 
Table 3

Prevalence and categories of flares from the time of conception and in trimesters among pregnant SLE patients and their controls (according to their disease activity at the time of conception)

\begin{tabular}{|c|c|c|c|c|c|c|c|c|c|}
\hline & & & $\begin{array}{l}1 \text { st } \\
\text { trimester }\end{array}$ & & $\begin{array}{l}\text { 2nd } \\
\text { trimester }\end{array}$ & & $\begin{array}{l}\text { 3rd } \\
\text { trimester }\end{array}$ & & Overall \\
\hline & & N/N1 & $\begin{array}{l}\text { n1 (\%): } \\
\text { n2 (\%) }\end{array}$ & N/N1 & $\begin{array}{l}\text { n1 (\%): } \\
\text { n2 (\%) }\end{array}$ & N/N1 & $\begin{array}{l}\text { n1 (\%): } \\
\text { n2 (\%) }\end{array}$ & N/N1 & $\begin{array}{l}\text { n 1(\%): } \\
\text { n2 (\%) }\end{array}$ \\
\hline \multirow[t]{3}{*}{ All cases } & $\begin{array}{l}\text { Pregnancy } \\
\text { group }\end{array}$ & $19 / 90$ & $\begin{array}{l}3(15.79) \\
: 16 \\
(84.21)\end{array}$ & $12 / 82$ & $\begin{array}{l}5(41.67) \\
: 7 \\
(58.33)\end{array}$ & $6 / 71$ & $\begin{array}{l}1(16.67) \\
: 5 \\
(83.33)\end{array}$ & $37 / 90$ & $\begin{array}{l}9(24.32): \\
28 \\
(75.68)\end{array}$ \\
\hline & $\begin{array}{l}\text { Control } \\
\text { group }\end{array}$ & $7 / 90$ & $\begin{array}{l}2(28.57) \\
: 5 \\
(71.43)\end{array}$ & $12 / 82$ & $\begin{array}{l}6(50.00) \\
: 6 \\
(50.00)\end{array}$ & 7/71 & $\begin{array}{l}4(57.14) \\
: 3 \\
(42.86)\end{array}$ & $26 / 90$ & $\begin{array}{l}12 \\
(46.15): \\
14 \\
(53.85)\end{array}$ \\
\hline & $p$-value & & 0.588 & & 0.682 & & 0.266 & & 0.070 \\
\hline \multirow[t]{3}{*}{ Remission } & $\begin{array}{l}\text { Pregnancy } \\
\text { group }\end{array}$ & $9 / 57$ & $\begin{array}{l}0: 9 \\
(100.00)\end{array}$ & $10 / 50$ & $\begin{array}{l}5(50.00) \\
: 5 \\
(50.00)\end{array}$ & $3 / 45$ & $\begin{array}{l}0: 3 \\
(100.00)\end{array}$ & $22 / 57$ & $\begin{array}{l}5(22.73): \\
17 \\
(77.27)\end{array}$ \\
\hline & $\begin{array}{l}\text { Control } \\
\text { group }\end{array}$ & $5 / 40$ & $\begin{array}{l}1(20.00) \\
: 4 \\
(80.00)\end{array}$ & $7 / 38$ & $\begin{array}{l}3(42.86) \\
: 4 \\
(57.14)\end{array}$ & $2 / 32$ & $\begin{array}{l}1(50.00) \\
: 1 \\
(50.00)\end{array}$ & $14 / 40$ & $\begin{array}{l}5(35.71): \\
9(64.29)\end{array}$ \\
\hline & $p$-value & & 0.357 & & 1.000 & & 0.400 & & 0.396 \\
\hline \multirow[t]{3}{*}{ Mild } & $\begin{array}{l}\text { Pregnancy } \\
\text { group }\end{array}$ & $6 / 22$ & $\begin{array}{l}3(50.00) \\
: 3 \\
(50.00)\end{array}$ & $1 / 21$ & $\begin{array}{l}0: 1 \\
(100.00)\end{array}$ & $3 / 19$ & $\begin{array}{l}1(33.33) \\
: 2 \\
(66.67)\end{array}$ & $10 / 22$ & $\begin{array}{l}4(40.00): \\
6(60.00)\end{array}$ \\
\hline & $\begin{array}{l}\text { Control } \\
\text { group }\end{array}$ & $1 / 28$ & $\begin{array}{l}0: 1 \\
(100.0)\end{array}$ & $5 / 25$ & $\begin{array}{l}3(60.00) \\
: 2 \\
(40.00)\end{array}$ & $3 / 20$ & $\begin{array}{l}2(66.67) \\
: 1 \\
(33.33)\end{array}$ & $9 / 28$ & $\begin{array}{l}5(55.56): \\
4(44.44)\end{array}$ \\
\hline & $p$-value & & 1.000 & & 1.000 & & 1.000 & & 0.656 \\
\hline \multirow{3}{*}{$\begin{array}{l}\text { Moderate } \\
\text { and high } \\
\text { disease } \\
\text { activity }\end{array}$} & $\begin{array}{l}\text { Pregnancy } \\
\text { group }\end{array}$ & $4 / 11$ & $\begin{array}{l}0: 4 \\
(100.00)\end{array}$ & $1 / 11$ & $\begin{array}{l}0: 1 \\
(100.00)\end{array}$ & $0 / 7$ & $0: 0$ & $5 / 11$ & $\begin{array}{l}0: 5 \\
(100.00)\end{array}$ \\
\hline & $\begin{array}{l}\text { Control } \\
\text { group }\end{array}$ & $1 / 22$ & $\begin{array}{l}1 \\
(100.00): \\
0\end{array}$ & $0 / 19$ & $0: 0$ & $2 / 19$ & $\begin{array}{l}1(50.00) \\
: 1 \\
(50.00)\end{array}$ & $3 / 22$ & $\begin{array}{l}2(66.67): \\
1(33.33)\end{array}$ \\
\hline & $p$-value & & 0.200 & & & & & & 0.107 \\
\hline
\end{tabular}

\section{Effect of pregnancy termination or delivery on SLE disease activity and flares}

To determine the effect of pregnancy termination or delivery on SLE disease activity, the mSLEDAI-2K score at the time of last visit prior to pregnancy termination (either by spontaneous or induced abortion, stillbirth or dead fetus in the utero) or delivery was compared with that of the post-partum visit (Table 4). There was no significant difference in the 
mSLEDAI-2K score between that at the last visit prior to pregnancy termination or delivery and that in the post-partum period in all of the pregnancy and control group, no matter whether they had a flare or not. There also was no significant difference in the mSLEDAI-2K score between the last visit prior to pregnancy termination or delivery and the post-partum period among those with successful pregnancy or pregnancy loss, no matter whether there was a flare or not.

Table 4

SLE disease activity at the time of last visit prior to pregnancy termination or delivery and at the time of post-partum visit in the pregnancy and control group

\begin{tabular}{|c|c|c|c|c|}
\hline \multirow[t]{2}{*}{ Group } & \multirow[t]{2}{*}{ Flare status } & \multicolumn{3}{|c|}{ SLE disease activity (mSLEDAl-2K) } \\
\hline & & $\begin{array}{l}\text { Last visit prior to pregnancy } \\
\text { termination or } \\
\text { delivery } \\
\text { (Mean } \pm \text { SEM) }\end{array}$ & $\begin{array}{l}\text { post-partum period } \\
\text { (Mean } \pm \text { SEM) }\end{array}$ & p-value \\
\hline \multirow[t]{3}{*}{ Pregnancy group } & $N=90$ & $2.61 \pm 0.40$ & $2.50 \pm 0.38$ & 0.713 \\
\hline & No flare $(n=48)$ & $1.33 \pm 0.42$ & $1.25 \pm 0.42$ & 0.312 \\
\hline & Flare $(n=42)$ & $4.07 \pm 0.64$ & $3.93 \pm 0.61$ & 0.823 \\
\hline \multirow[t]{3}{*}{ Control group } & $N=90$ & $2.81 \pm 0.42$ & $2.26 \pm 0.39$ & 0.074 \\
\hline & No flare $(n=60)$ & $2.13 \pm 0.48$ & $2.10 \pm 0.48$ & 0.654 \\
\hline & Flare $(n=30)$ & $4.17 \pm 0.76$ & $2.57 \pm 0.69$ & 0.073 \\
\hline \multirow[t]{3}{*}{ Successful pregnancy } & $N=71$ & $2.58 \pm 0.46$ & $2.27 \pm 0.43$ & 0.350 \\
\hline & No flare $(n=37)$ & $0.97 \pm 0.42$ & $0.97 \pm 0.42$ & \\
\hline & Flare $(n=4)$ & $4.32 \pm 0.75$ & $3.68 \pm 0.71$ & 0.347 \\
\hline \multirow[t]{3}{*}{ Pregnancy loss } & $N=19$ & $2.74 \pm 0.75$ & $3.37 \pm 0.82$ & 0.355 \\
\hline & No flare $(n=11)$ & $2.54 \pm 1.11$ & $2.18 \pm 1.13$ & 0.294 \\
\hline & Flare $(\mathrm{n}=8)$ & $3.00 \pm 1.00$ & $5.00 \pm 1.00$ & 0.052 \\
\hline \multicolumn{5}{|c|}{$\begin{array}{l}\text { The repeated measures mixed model was used for analysis and controlled by age at SLE onset, mSLEDAI-2K score, } \\
\text { daily dose of prednisolone and use of immunosuppressive drugs. } N=\text { number of pregnancies, } n=\text { number of events, } \\
\text { mSLEDAI-2K = modified the Systemic Lupus Erythematosus Disease Activity Index }-2000 \text {. }\end{array}$} \\
\hline
\end{tabular}

SLE disease activity during the post-partum period was compared between the pregnancy and control group (Table 5). There was no significant difference in the mSLEDAI-2K score between the two groups. Although the number of flares was higher numerically in the pregnancy group than in the controls, it did not reach a statistically significant difference ( $46.67 \%$ vs. $33.33 \%, p=0.091)$. Similarly, in the subgroup analysis according to flare categories, the pregnancy group had numerically more severe flares than the controls, but they did not reach statistical significance $(76.19 \%$ vs. $53.33 \%$, $p=0.095)$. 
Table 5

Disease activity and flares at the post-partum period among pregnant SLE patients and their controls

p-value

\section{SLE disease activity (mSLEDAl-2K score)}

$\begin{array}{llll}\text { Pregnancy group, } \mathrm{n}=90 & \text { Mean } \pm \text { SEM } & 2.50 \pm 0.38 & 0.354 \\ \text { Control group, } \mathrm{n}=90 & \text { Mean } \pm \text { SEM } & 2.26 \pm 0.39\end{array}$

\section{Any post-partum flares, $\mathrm{n}(\%)$}

\begin{tabular}{llll} 
Pregnancy group & No. flares/No. of pregnancy (\%) & $42 / 90(46.67)$ & 0.129 \\
\hline Control group & No. flares/No. of pregnancy (\%) & $30 / 90(33.33)$
\end{tabular}

Flare category, $\mathrm{n}(\%)$

$\begin{array}{llr}\text { Pregnancy group } & \text { Mild or moderate flare } & 10(23.81) \\ & \text { Severe flare } & 32(76.19) \\ \text { Control group } & \text { Mild or moderate flare } & 14(46.67) \\ & \text { Severe flare } & 16(53.33)\end{array}$

The ANCOVA for continuous response and logistic regression for binary response was used for analysis and controlled by age at SLE onset, mSLEDAI-2K score, daily dose of prednisolone, and use of immunosuppressive drugs. mSLEDAl-2K = modified Systemic Lupus Erythematosus Disease Activity Index - 2000.

\section{Discussion}

This controlled study of Thai pregnant SLE patients compared to non-pregnant SLE patients matched with age, sex and disease duration found that SLE disease activity, starting from - 6M to pregnancy and the post-partum period, was comparable between the pregnant SLE patients and their controls. However, it did not show any significant differences, except at the time of conception when disease activity in the control group (all the control patients and the subgroup of control patients with disease in remission at $-6 \mathrm{M}$ ) was slightly but significantly higher than that in the pregnancy group. There also was no significant difference in the incidence or severity of flares between the 2 groups throughout pregnancy and in the post-partum period.

Studies of disease exacerbation or flares in pregnant SLE patients have been performed in several groups, and even among the case-controlled studies, have shown conflicting results [4-10,21]. Details of patient characteristics and flares among previous case-controlled studies, as well as this study, are shown in Supplementary Table 2. All of the studies, including this one, collected data prospectively, except that of Meehan et al. [7], which was a retrospective study. Three studies performed by Lockshin et al. [10], Meethan et al. [7] and Urowitz et al. [4] found no increase in rate of flare among pregnant SLE patients when compared with non-pregnant SLE controls. Among these studies, all of the controls were matched with the pregnant cases by age, disease duration, and organ involvement or disease activity. It is interesting that in the study by Lockshin et al. [10] disease activity in the pregnancy group tended to be lower than that in the controls, but it did not reach statistical significance. In contrast, studies by Minzt et al. [8], Wong et al. [9], Petri et al. [5] and Ruiz-Irastorza et al. [6] found that pregnant SLE patients had significantly higher flare rates at the same time during pregnancy than their controls. However, although these studies used non-pregnant SLE patients as their controls, they were not matched with age or disease duration, except for those in the study of Ruiz-Irastorza et al., who were matched with age. Furthermore, the report by Mintz et al. [8] used normal healthy pregnant women as the controls 
rather than SLE patients. In the report by Petri et al. [5], the mean age of the controls was significantly higher than that of the SLE cases (5 years). The same group re-analyzed the effect of pregnancies on SLE disease activity 27 years later, and although the mean age of both groups was comparable, they still found that flare was more common in pregnant SLE patients than in their non-pregnant SLE controls [21].

The difference in whether there is increasing flare in pregnant SLE patients when compared with non-pregnant SLE patients, even in a controlled study, might be explained partly by the difference in SLE disease activity measurements/instruments, definition of flares and flare instruments, and number of patients who still had active disease at the time of conception (Supplementary Table 2). However, when looking at the above studies and this one carefully, those that showed no increase in flare rate matched their controls with age, disease duration, organ involvement or disease activity in their study design; whereas those that showed an increase in flare rate did not match their controls with the above variables. It is necessary for subjects to be matched carefully in case-control studies. Nonrandom selection of the controls can cause un-recognized bias and influence analysis outcomes. Therefore, the controls unmatched with age, disease duration, and organ involvement or disease activity might explain the difference in the results of these studies.

This study found a flare rate during pregnancy of $41.11 \%$, and $46.67 \%$ during the post-partum period, giving an overall flare incidence of $87.78 \%$. The highest incidence of flares was observed during the post-partum period. This might be due to the study including all of the flares that occurred after pregnancy termination or delivery, when increasing dosage of corticosteroids or an addition of immunosuppressive therapy was given to control SLE; thus, the flares were counted in order to comply with flare definition according to the SFI [20]. The incidence of flares during each trimester and the post-partum period in this study, and some selected previous reports [4-9, 22-25], are shown in Table 6 . There was a wide range in the incidence of flares among previous study reports. Moreover, the highest incidence of flares occurred differently among trimesters and in the post-partum period. Again, these differences might have been due to several factors, including the ethnic group of the patients studied, period of the study, methods used to determine disease activity, flare definition and measurement instruments, and number of patients who still had active disease at the time of conception. 
Table 6

Incidence of flares according to the trimester and post-partum period in patients with SLE (selected series)

\begin{tabular}{|c|c|c|c|c|c|c|c|c|}
\hline $\begin{array}{l}\text { Authors, } \\
\text { year } \\
\text { [reference] }\end{array}$ & $\begin{array}{l}\text { Period } \\
\text { of } \\
\text { study }\end{array}$ & $\mathrm{n} / \mathrm{N}$ & $\begin{array}{l}\text { No. of } \\
\text { pregnancies } \\
\text { with active } \\
\text { disease at } \\
\text { conception } \\
(\%)\end{array}$ & $\begin{array}{l}\text { Overall } \\
\text { flare } \\
\text { incidence, } \\
\text { n1/n (\%) }\end{array}$ & $\begin{array}{l}\text { 1st } \\
\text { trimester, } \\
(\%)\end{array}$ & $\begin{array}{l}\text { 2nd } \\
\text { trimester, } \\
(\%)\end{array}$ & $\begin{array}{l}3 \\
\text { trimester, } \\
(\%)\end{array}$ & $\begin{array}{l}\text { Post- } \\
\text { partum, } \\
(\%)\end{array}$ \\
\hline $\begin{array}{l}\text { Mintz et } \\
\text { al, } 1986 \\
\text { [8] }\end{array}$ & $\begin{array}{l}1974- \\
1983\end{array}$ & $102 / 75$ & $\begin{array}{l}10 / 102 \\
(9.80)\end{array}$ & $\begin{array}{l}55 / 92^{c} \\
(59.78)\end{array}$ & $\begin{array}{l}30 / 55 \\
(54.55)\end{array}$ & $\begin{array}{l}7 / 55 \\
(12.72)\end{array}$ & $\begin{array}{l}7 / 55 \\
(12.72)\end{array}$ & $\begin{array}{l}11 / 55 \\
(20)\end{array}$ \\
\hline $\begin{array}{l}\text { Meehan et } \\
\text { al., } 1987 \\
\text { [7] }\end{array}$ & $\begin{array}{l}1970- \\
1981\end{array}$ & $22 / 22$ & $N A^{d}$ & $\begin{array}{l}10 / 22 \\
(45.45)\end{array}$ & $\begin{array}{l}6 / 10 \\
(60.00)\end{array}$ & $\begin{array}{l}2 / 10 \\
(10.00)\end{array}$ & $\begin{array}{l}1 / 10 \\
(10.00)\end{array}$ & $\begin{array}{l}1 / 10 \\
(10.00)\end{array}$ \\
\hline $\begin{array}{l}\text { Petri et al., } \\
1991 \text { [5] }\end{array}$ & $\begin{array}{l}1987- \\
1991\end{array}$ & $40 / 37$ & NA & $\begin{array}{l}34 / 37 \\
(91.89)\end{array}$ & $\begin{array}{l}6 / 34 \\
(17.67)\end{array}$ & $\begin{array}{l}16 / 34 \\
(47.06)\end{array}$ & $\begin{array}{l}5 / 34 \\
(14.71)\end{array}$ & $\begin{array}{l}7 / 34 \\
(20.59)\end{array}$ \\
\hline $\begin{array}{l}\text { Wong et } \\
\text { al. } 1991 \\
\text { [9] }\end{array}$ & $\begin{array}{l}1985- \\
1989\end{array}$ & $29 / 22$ & $\begin{array}{l}13 / 29 \\
(44.83)\end{array}$ & $\begin{array}{l}13 / 29 \\
(44.83)\end{array}$ & $\begin{array}{l}3 / 13 \\
(23.08)\end{array}$ & $\begin{array}{l}5 / 13 \\
(38.46)\end{array}$ & $\begin{array}{l}5 / 13 \\
(38.46)\end{array}$ & $0 / 29(0)$ \\
\hline $\begin{array}{l}\text { Urowitz et } \\
\text { al., } 1993 \\
{[4]}\end{array}$ & $\begin{array}{l}1970- \\
1988\end{array}$ & $79 / 46$ & $\begin{array}{l}37 / 79 \\
(46.84)\end{array}$ & $\begin{array}{l}32 / 61^{\mathrm{e}} \\
(52.47)\end{array}$ & $\begin{array}{l}15 / 32 \\
(46.88)\end{array}$ & $\begin{array}{l}10 / 32 \\
(31.25)\end{array}$ & $\begin{array}{l}4 / 32 \\
(12.50)\end{array}$ & $\begin{array}{l}3 / 32 \\
(9.38)\end{array}$ \\
\hline $\begin{array}{l}\text { Ruiz- } \\
\text { Irastorza, } \\
\text { et al., } \\
1996 \text { [6] }\end{array}$ & $\begin{array}{l}1992- \\
1996\end{array}$ & $78 / 68$ & NA & $\begin{array}{l}51 / 78 \\
(65.38)\end{array}$ & $\begin{array}{l}2 / 78^{f} \\
(2.56)\end{array}$ & $\begin{array}{l}34 / 71^{f} \\
(47.89)\end{array}$ & $\begin{array}{l}9 / 63^{f} \\
(24.29)\end{array}$ & $\begin{array}{l}27 / 78^{f} \\
(34.62)\end{array}$ \\
\hline $\begin{array}{l}\text { Carmona } \\
\text { et al., } \\
1999 \text { [22] }\end{array}$ & $\begin{array}{l}1985- \\
1996\end{array}$ & $60 / 46$ & $4 / 60(6.67)$ & $\begin{array}{l}15 / 60 \\
(25.00)\end{array}$ & $\begin{array}{l}2 / 15 \\
(13.33)\end{array}$ & $\begin{array}{l}6 / 15 \\
(40.00)\end{array}$ & $\begin{array}{l}2 / 15 \\
(13.33)\end{array}$ & $\begin{array}{l}5 / 15 \\
(33.33)\end{array}$ \\
\hline $\begin{array}{l}\text { Cortes- } \\
\text { Hernandez } \\
\text { et al., } \\
2002 \text { [23] }\end{array}$ & $\begin{array}{l}1984- \\
1999\end{array}$ & $103 / 60$ & $\begin{array}{l}7 / 103 \\
(7.47)\end{array}$ & $\begin{array}{l}39 / 103 \\
(37.86)\end{array}$ & $\begin{array}{l}5 / 39 \\
(12.82)\end{array}$ & $\begin{array}{l}10 / 39 \\
(25.64)\end{array}$ & $\begin{array}{l}4 / 39 \\
(10.26)\end{array}$ & $\begin{array}{l}20 / 39 \\
(51.28)\end{array}$ \\
\hline $\begin{array}{l}\text { Naseri et } \\
\text { al., } 2018 \\
{[24]}\end{array}$ & $\begin{array}{l}2002- \\
2012\end{array}$ & $69 / 58$ & $(20.00)$ & $\begin{array}{l}34 / 69 \\
(49.28)\end{array}$ & $\begin{array}{l}3 / 34 \\
(8.82)\end{array}$ & $\begin{array}{l}8 / 34 \\
(23.53)\end{array}$ & $\begin{array}{l}16 / 34 \\
(47.06)\end{array}$ & $\begin{array}{l}7 / 34 \\
(20.59)\end{array}$ \\
\hline $\begin{array}{l}\text { Chen et } \\
\text { al., } 2018 \\
\text { [25] }\end{array}$ & $\begin{array}{l}2011- \\
2016\end{array}$ & $243 / 243$ & NA & $\begin{array}{l}42 / 243 \\
(21.40)\end{array}$ & $\begin{array}{l}8 / 42 \\
(19.05)\end{array}$ & $\begin{array}{l}15 / 42 \\
(35.71)\end{array}$ & $\begin{array}{l}29 / 42 \\
(69.05)\end{array}$ & NA \\
\hline This study & $\begin{array}{l}1993- \\
2018\end{array}$ & $90 / 77$ & $\begin{array}{l}33 / 90 \\
(36.67)\end{array}$ & $\begin{array}{l}79 / 90 \\
(87.78)\end{array}$ & $\begin{array}{l}19 / 90^{f} \\
(21.11)\end{array}$ & $\begin{array}{l}28 / 82^{f} \\
(34.15)\end{array}$ & $\begin{array}{l}28 / 71^{f} \\
(39.44)\end{array}$ & $\begin{array}{l}42 / 90^{f} \\
(46.67)\end{array}$ \\
\hline \multicolumn{9}{|c|}{$\begin{array}{l}a=\text { from the } 1 \text { st trimester to post-partum period, }{ }^{b}=\text { number of flares among all of the flares, }{ }^{c}=\text { among inactive } \\
\text { pregnancies, }{ }^{d}=\text { all pregnant patients who received corticosteroids or azathioprine, } e=\text { among patients ending with } \\
61 \text { deliveries, }{ }^{f}=\text { number of patients at risk. }\end{array}$} \\
\hline
\end{tabular}

It should be noted in this study that patients with moderate and high disease activity at -6M had their disease activity decline gradually during the pregnancy period. This might be explained by when the physician recognized that their SLE 
patients had increased disease activity or flare, they increased the treatment to control it. Ten pregnancies with moderate and high disease activity at $-6 \mathrm{M}$ received prednisolone at $22.50 \pm 10.34 \mathrm{mg} / \mathrm{day}$. The other medications were hydroxychloroquine in 4 pregnancies, cyclophosphamide in 4 , and azathioprine in one. Of these 10 pregnancies, there were 4 fetal losses.

There were some limitations in this study. Firstly, the age at SLE diagnosis in the pregnancy group was slightly but significantly less than that in the controls. However, this small difference in age (2.5 years) should not have a significant effect on the clinical manifestation of the disease. Also, at the time of conception, the control group had slightly but significantly higher disease activity (mSLEDAI-2K score), received significantly more daily doses of prednisolone and significantly received more immunosuppressive drugs. However, the difference in this mSLEDAI-2K score $(<2)$ might not have significance in clinical practice. However, these significant differences was controlled during the analysis which could these effects on the statistical results. Secondly, this study used the mSLEDAI-2K instrument (not including anti-dsDNA and complements) to determine disease activity, thus it might not reflect the "standard" disease activity measurement as the original development [26]. However, the mSLEDAI-2K instrument has not only shown very good correlation with the original SLEDAI-2K [17], but also its effective use in clinical studies and clinical trials [27-30]. Thirdly, the severity of SLE also was modified as it did not use the original SLEDAl score [19], and the flare and degree of flare was captured using the $\mathrm{mSFI}$, which did not included the PGA as in the original description [20]. Therefore, this score could misclassify the degree of SLE severity, and degree of flare to be less than it should be. However, this modification was used in both the pregnancy and control group, therefore, the difference would be minimal between the two groups in the analysis. It is interesting that a recent study by Eudy et al. [21] showed similar results in the incidence of flare during pregnancy determined by either the PGA or SFI. Lastly, the ratio of controls to cases in this study was 1:1, which might affect the power of the analysis. This was due to difficulty finding controls that had similar age at SLE diagnosis, age at onset of pregnancy, duration of follow up matched to that of the cases.

Despite the limitations in this study, there were some strengths. This study used controls matched with age at disease onset and disease duration prior to onset of pregnancy, which allowed the best match with the pregnant patients, and avoided un-recognized bias. The mSLEDAl score utilized is a standard instrument that determines SLE disease activity, and has been validated and used in clinical practice. Although the modified standard SLE disease severity categories [19] and modified SFI [20] were used, they could capture changes in disease activity, severity and flares according to standard practice in clinical studies. The number of patients in this control study was not too small when compared with previous controlled-studies, except for that of Mintz et al. [8] and Eudy et al. [21]. Lastly, this study started comparing disease activity and flares from $-6 \mathrm{M}$ which differed from other previous studies that started comparing at the time of conception, and this could be another strength.

\section{Conclusions}

This study found that the disease activity from $-6 \mathrm{M}$ to the post-partum period in the pregnant SLE patients was generally no different to that in the non-pregnant SLE controls matched with sex, age and disease duration; except for disease activity in all of the control group and the controls with disease remission at $-6 \mathrm{M}$ had slight, but significantly higher disease activity than that in the pregnancy group. However, the rate of flare and flare severity categories were no different between the two groups. The flare incidence was highest at the post-partum period. More studies with age and disease duration matched controls, and probably a larger number of patients, are needed to confirm these findings.

\section{Abbreviations}

$-3 \mathrm{M}=3$ months prior to conception

Page 17/21 
$-6 \mathrm{M}=6$ months prior to conception

PGA = Physician Global Assessment

SELENA-SLEDAI = Safety of Estrogens in Lupus Erythematosus National Assessment

SFI $=$ the SELENA-SLEDAI Flare Index

SLE $=$ Systemic Lupus Erythematosus

SLEDAI = Systemic Lupus Erythematosus Disease Activity Index

SLEDAI-2K = Systemic Lupus Erythematosus Disease Activity Index -2000

SLEPDAI = Systemic Lupus Erythematosus Pregnancy Disease Activity Index

$\mathrm{mSFI}=$ modified SELENA-SLEDAI Flare Index

mSLEDAI-2K = modified Systemic Lupus Erythematosus Disease Activity Index -2000

mSLEPDAI = modified Systemic Lupus Erythematosus Pregnancy Disease Activity Index

\section{Declarations}

\section{Ethic approval and consent to participate}

This study was performed in accordance with the ethical standards of the institutional and/or national research committee and the 1964 Declaration of Helsinki and its later amendments or comparable ethical standards. It was approved by the Ethic Committee of the Faculty of Medicine, Chiang Mai University (No. 215/2017). The consent for participation was waived.

\section{Consent for publication}

Not applicable

\section{Availability of data and materials}

The datasets used and/or analyzed in this study are available from the corresponding author on reasonable request

\section{Competing of interest}

All authors declare that they have no competing interests

\section{Funding}

None

\section{Authors' contributions}

WL - made a substantial contribution to the conception and design, acquisition of data, analysis, interpretation of data, and drafting and revising the manuscript. 
TT - made a substantial contribution to the conception and design, acquisition of data, and critically revising the important intellectual content of the manuscript.

NK - made a substantial contribution to acquiring the data, and critically revising the important intellectual content of the manuscript.

AW - made a substantial contribution to the analysis, interpretation of data and critically revising the important intellectual content of the manuscript.

All of the authors approved the final version of the manuscript for submitting for publication. Dr. Louthrenoo had full access to all of the data in this study and takes responsibility for its integrity, and accuracy of the data and analysis.

\section{Acknowledgements}

The authors thank Mrs. Waraporn Sukitawut, Ms. Saowanee Pantana and Ms. Phimwalan Konkaeo for their secretarial assistance.

\section{References}

1. Cervera R, Font J, Carmona F, Balasch J: Pregnancy outcome in systemic lupus erythematosus: good news for the new millennium. Autoimmun Rev. 2002,1(6):354-9.

2. Lateef A, Petri M: Systemic Lupus Erythematosus and Pregnancy. Rheum Dis Clin North Am. 2017,43(2):215-26.

3. Stojan G, Baer AN: Flares of systemic lupus erythematosus during pregnancy and the puerperium: prevention, diagnosis and management. Expert Rev Clin Immunol. 2012,8(5):439-53.

4. Urowitz MB, Gladman DD, Farewell VT, Stewart J, McDonald J: Lupus and pregnancy studies. Arthritis Rheum. 1993,36(10):1392-7.

5. Petri M, Howard D, Repke J: Frequency of lupus flare in pregnancy. The Hopkins Lupus Pregnancy Center experience. Arthritis Rheum. 1991,34(12):1538-45.

6. Ruiz-Irastorza G, Lima F, Alves J, Khamashta MA, Simpson J, Hughes GR, et al.: Increased rate of lupus flare during pregnancy and the puerperium: a prospective study of 78 pregnancies. Br J Rheumatol. 1996,35(2):133-8.

7. Meehan RT, Dorsey JK: Pregnancy among patients with systemic lupus erythematosus receiving immunosuppressive therapy. J Rheumatol. 1987,14(2):252-8.

8. Mintz G, Niz J, Gutierrez G, Garcia-Alonso A, Karchmer S: Prospective study of pregnancy in systemic lupus erythematosus. Results of a multidisciplinary approach. J Rheumatol. 1986,13(4):732-9.

9. Wong KL, Chan FY, Lee CP: Outcome of pregnancy in patients with systemic lupus erythematosus. A prospective study. Arch Intern Med. 1991,151(2):269-73.

10. Lockshin MD, Reinitz E, Druzin ML, Murrman M, Estes D: Lupus pregnancy. Case-control prospective study demonstrating absence of lupus exacerbation during or after pregnancy. Am J Med. 1984,77(5):893-8.

11. Mina R, Brunner HI: Update on differences between childhood-onset and adult-onset systemic lupus erythematosus. Arthritis Res Ther. 2013,15(4):218.

12. Merola JF, Bermas B, Lu B, Karlson EW, Massarotti E, Schur PH, et al.: Clinical manifestations and survival among adults with (SLE) according to age at diagnosis. Lupus. 2014,23(8):778-84.

13. Bundhun PK, Kumari A, Huang F: Differences in clinical features observed between childhood-onset versus adultonset systemic lupus erythematosus: A systematic review and meta-analysis. Medicine (Baltimore).

2017,96(37):e8086.

Page 19/21 
14. Gyori N, Giannakou I, Chatzidionysiou K, Magder L, van Vollenhoven RF, Petri M: Disease activity patterns over time in patients with SLE: analysis of the Hopkins Lupus Cohort. Lupus Sci Med. 2017,4(1):e000192.

15. Swaak AJ, van den Brink HG, Smeenk RJ, Manger K, Kalden JR, Tosi S, et al.: Systemic lupus erythematosus: clinical features in patients with a disease duration of over 10 years, first evaluation. Rheumatology (Oxford). 1999,38(10):953-8.

16. Hochberg MC: Updating the American College of Rheumatology revised criteria for the classification of systemic lupus erythematosus. Arthritis Rheum. 1997,40(9):1725.

17. Uribe AG, Vila LM, McGwin G, Jr., Sanchez ML, Reveille JD, Alarcon GS: The Systemic Lupus Activity Measurerevised, the Mexican Systemic Lupus Erythematosus Disease Activity Index (SLEDAI), and a modified SLEDAI-2K are adequate instruments to measure disease activity in systemic lupus erythematosus. J Rheumatol. 2004,31(10):1934-40.

18. Buyon JP, Kalunian KC, Ramsey-Goldman R, Petri MA, Lockshin MD, Ruiz-Irastorza G, et al.: Assessing disease activity in SLE patients during pregnancy. Lupus. 1999,8(8):677-84.

19. Abrahamowicz M, Fortin PR, du Berger R, Nayak V, Neville C, Liang MH: The relationship between disease activity and expert physician's decision to start major treatment in active systemic lupus erythematosus: a decision aid for development of entry criteria for clinical trials. J Rheumatol. 1998,25(2):277-84.

20. Buyon JP, Petri MA, Kim MY, Kalunian KC, Grossman J, Hahn BH, et al.: The effect of combined estrogen and progesterone hormone replacement therapy on disease activity in systemic lupus erythematosus: a randomized trial. Ann Intern Med. 2005,142(12 Pt 1):953-62.

21. Eudy AM, Siega-Riz AM, Engel SM, Franceschini N, Howard AG, Clowse MEB, et al.: Effect of pregnancy on disease flares in patients with systemic lupus erythematosus. Ann Rheum Dis. 2018,77(6):855-60.

22. Carmona F, Font J, Cervera R, Munoz F, Cararach V, Balasch J: Obstetrical outcome of pregnancy in patients with systemic Lupus erythematosus. A study of 60 cases. Eur J Obstet Gynecol Reprod Biol. 1999,83(2):137-42.

23. Cortes-Hernandez J, Ordi-Ros J, Paredes F, Casellas M, Castillo F, Vilardell-Tarres M: Clinical predictors of fetal and maternal outcome in systemic lupus erythematosus: a prospective study of 103 pregnancies. Rheumatology (Oxford). 2002,41(6):643-50.

24. Naseri EP, Surita FG, Borovac-Pinheiro A, Santos M, Appenzeller S, Costallat LTL: Systemic Lupus Erythematosus and Pregnancy: A Single-Center Observational Study of 69 Pregnancies. Rev Bras Ginecol Obstet. 2018,40(10):58792.

25. Chen D, Lao M, Zhang J, Zhan Y, Li W, Cai X, et al.: Fetal and Maternal Outcomes of Planned Pregnancy in Patients with Systemic Lupus Erythematosus: A Retrospective Multicenter Study. J Immunol Res. 2018,2018:2413637.

26. Gladman DD, Ibanez D, Urowitz MB: Systemic lupus erythematosus disease activity index 2000. J Rheumatol. 2002,29(2):288-91.

27. Kasitanon N, Intaniwet T, Wangkaew S, Pantana S, Sukitawut W, Louthrenoo W: The clinically quiescent phase in early-diagnosed SLE patients: inception cohort study. Rheumatology (Oxford). 2015,54(5):868-75.

28. Frodlund M, Wettero J, Dahle C, Dahlstrom O, Skogh T, Ronnelid J, et al.: Longitudinal anti-nuclear antibody (ANA) seroconversion in systemic lupus erythematosus: a prospective study of Swedish cases with recent-onset disease. Clin Exp Immunol. 2020,199(3):245-54.

29. Maciel RO, Ferreira GA, Akemy B, Cardoso F: Executive dysfunction, obsessive-compulsive symptoms, and attention deficit and hyperactivity disorder in Systemic Lupus Erythematosus: Evidence for basal ganglia dysfunction? J Neurol Sci. 2016,360:94-7.

30. Hermann V, Batalov A, Smakotina S, Juif PE, Cornelisse P: First use of cenerimod, a selective S1P1 receptor modulator, for the treatment of SLE: a double-blind, randomised, placebo-controlled, proof-of-concept study. Lupus 
Sci Med. 2019,6(1):e000354.

\section{Supplementary Files}

This is a list of supplementary files associated with this preprint. Click to download.

- PreviouscontrolledstudiesonflaresinSLE.docx

- ActiveorganinvolvementduringpregnancyinSLE.docx

- ChangesinmSLEDAlscoresduringpregnancy.docx 